\title{
MIR145 Gene
}

National Cancer Institute

\section{Source}

National Cancer Institute. MIR145 Gene. NCI Thesaurus. Code C81740.

This gene is involved in the regulation of gene expression and plays a role in the development of colorectal and prostate carcinomas as well as chronic lymphocytic leukemia, Burkitt lymphoma and diffuse large B-cell lymphoma. 